\title{
THE LINGUISTIC LANDSCAPE OF TOURISM: MULTILINGUAL SIGNS IN LITHUANIAN AND POLISH RESORTS
}

\author{
Jūratė Ruzaitè \\ Vytautas Magnus University
}

\begin{abstract}
The present study provides a snapshot of Polish and Lithuanian linguistic landscapes (LLs) in several resort cities situated in the border areas of the two countries. The data consists of 515 digital pictures of multilingual signs collected in the central and thus the most touristic parts of the cities. The main objectives in this research are to identify the authorship of multilingual signs, determine the types of establishments that employ multilingual signage, and analyse which languages coexist in popular tourist destinations. The interpretation of the results is grounded on the interrelation between multilingual signage, tourism as an important economic factor, and official language policies. The findings show that at least some major tendencies in language displays in LL do relate to tourist exchange and tourists' needs. However, some trends (e.g. absence of Russian in Polish LLs) need to be analysed with regard to symbolic, economic, and ideological values attached to non-titular languages.
\end{abstract}

Keywords: linguistic landscape, multilingual signs, Lithuanian, Polish, tourism, resorts, border area

DOI: https://doi.org/10.12697/jeful.2017.8.1.11

\section{Introduction}

The aim of the present study is to offer a sociolinguistic analysis of languages used in the multilingual linguistic landscape (henceforth, LL) of three major Lithuanian resort towns (Klaipeda, Palanga, and Druskininkai) and two Polish resort towns (Gdynia and Sopot), which are situated close to the international border areas in the two countries. This paper is based on photographic data collected in the period of 1 December 2013-31 December 2014. The results are interpreted by taking into account the interplay between multilingual signage, tourism as an important economic factor, and official language policy as a regulatory force. 
The present paper takes a primarily quantitative view of LL in different touristic locations by analysing the data distributionally. Signage in Polish and Lithuanian resort towns is analysed not as an indicator of ethnolinguistic vitality (as is perhaps the most common practice in LL studies), but as a form of discourse in a social situation where language displays are related primarily to the factors of tourism and the location of the research sites in the border area.

As is typical in research on public signage, the present study resorts to the definition of LL provided by Landry and Bourhis: "The language of public road signs, advertising billboards, street names, place names, commercial shop signs, and public signs on government buildings combines to form the linguistic landscape of a given territory, region, or urban agglomeration" (1997: 25). In other words, linguistic landscape "refers to the visibility and salience of languages on public and commercial signs" (Landry and Bourhis 1997: 23).

LL is thus perceived as a public space that enables language displays and consists of varied discourses and genre types, which are typically characterized by multimodality and multilingualism. At the surface level, public space may seem to offer an open area for versatile language exposures, but in practice it often turns into an arena of ideological and political struggle for ownership of space, representation, and control. Language displays are often predetermined by a variety of linguistic, economic, political, and other factors.

Tourism in this study has been selected as the main factor relied upon to explain the results observed in Polish and Lithuanian LLs. The state languages in Poland and Lithuania are "foreign" to tourists, and there might be attempts to shape signs by including other languages on them. Kallen (2009) observes that the use of the language "foreign" to tourists can have a dual effect on visitors. On the one hand, as he notes, it is precisely the encounter with " 'foreign' languages that constitutes an essential part of the tourist's experience of a voyage of foreign travel" (Kallen 2009: 271). The "foreign" language for a tourist is thus an immediate indication of authenticity in the new settings. Conversely, being an incomprehensible code for tourists, a "foreign" language in LL may also pose challenges to tourists and may decrease the sense of security. Therefore, it is important that creators of signage in touristic places take into account this dual nature of a foreign language in LL; LL should be shaped by taking into account the tourists' needs (Kallen 2009: 275). The following section deals with the approaches to LL and the interplay between LL and tourism in greater detail. 


\section{Linguistic landscape and tourism}

The early research on LL dates back to the 1970s (e.g. Masai 1972 and Rosenbaum et al. 1977; for a more detailed overview, see Spolsky 2009), but the main surge of interest in LL followed the publication of Landry and Bourhis (1997). Though LL is a relatively new field of studies, the huge interest in it has brought important developments in this diverse study field in terms of its definition, scope, applications, and analytic approaches to it. Due to space limitations, it is impossible to provide an exhaustive coverage of research on LL and approaches to it, but the main ones include language policy (e.g. Cenoz and Gorter 2006, Spolsky 2004, 2007, Backhaus 2009), sociolinguistics (for an exhaustive overview of LL as a sub-field of sociolinguistics, see Spolsky 2009), discourse analysis (e.g. Spolsky and Cooper 1991, Kallen 2009, Shohamy and Waksman 2009), semiotics and multimodal analysis (e.g. Scollon and Scollon 2003, Malinowski 2009, Jaworsky 2010, Sebba 2012, Peck and Banda 2014), as well as education and literacy (e.g. Dagenais 2009). LL is so manifold that it is approached from a multitude of theories, falls within a number of disciplines, and there is no coherent and independent theory to analyse it.

As distinguished by Landry and Bourhis (1997), LL performs two major functions. First, it can perform the informational function and thus can mark language boundaries between adjoining communities (e.g. in Quebec). The diversity of languages present on signs can also give information about the sociolinguistic composition of an area. Second, the symbolic function of LL implies that the presence of one's own language on signs can contribute to the feeling that this language has value and status within the sociolinguistic setting. LL can contribute to the vitality of competing ethnolinguistic groups in multilingual contexts. Due to the institutionalized nature of the public space, LL can provide rich data to study marginalized and dominant groups. Through LL, cultural ideals and the status of different groups within a given society can be explored (Reh 2004: 38). As Backhaus observes (2007: 11), LL provides evidence to determine overt and covert language attitudes, official language policies, and power relations between different groups.

The large body of existing research on LL stretches all over the world and has covered, at least to some extent, LL in such countries as Peru (Niño-Murcia 2003), China (Xiu and Li 2016), Japan (Backhaus 2006), Thailand (Huebner 2006), Taiwan (Curtin 2015), Malaysia (Manan 
et al. 2015), Israel (Ben-Rafael et al. 2006), Ecuador (Ovesdotter 2003), Uganda (Reh 2004), Netherlands (Edelman 2010), Portugal (Torkington 2014), Ireland (Moriarty 2014), and Italy (Coluzzi 2009), to mention just a few. LL has also received some attention in the postSoviet urban areas in Hungary (Petzold and Berns 2000), Azerbaijan (Shibliyev 2014), Ukraine (Pavlenko 2009, 2010), Russia (Yurchak 2000), the post-Eastern bloc in general (Gendelman and Aiello 2010), Latvia (Marten 2012, Pošeiko 2015), and Lithuania (Ruzaite 2006).

Research on LL typically transgresses the boundaries of pure linguistic analysis and is usually of an interdisciplinary nature. As such, it is most commonly examined from the perspectives of minority languages, tourism, and economy. In this paper, as has already been mentioned, the main focus is on the interplay between LL and tourism, which has already been tackled in some geographical contexts (e.g. Kallen 2009, Moriarty 2014, Torkington 2014, Libot and Lee 2014, Koschade 2016).

So far, relatively few studies have been of a comparative nature. The majority of existing studies have focused on single cities or single countries without directly comparing two or more countries; in addition, border areas still remain under-researched. Previous studies on LL in touristic spots most typically focus on the use of the local language as a token of local authenticity and often discuss the results with regard to language commodification.

Explorations of single sites are of a limited degree of comparability since they often differ in terms of data collection instruments and analytic approaches, data sampling criteria, choice of variables, data coding principles, and many other criteria. A focus on more than one geographical and socio-political context within the framework of a single study, however, can lead to a more consistent comparison. Some of the few comparative studies in central and eastern Europe include studies on LLs in medium-size towns in all the three Baltic States (Marten et al. 2012), LLs in Latvia (Marten et al. 2012, Pošeiko 2015), and research on the capitals of Moldova and Lithuania (Muth 2012).

The study design that is closest to the current research is that of Marten et al. (2012), who explored "six medium-sized towns in the Baltic States with regard to languages of tourism and to the role of English and Russian as linguae francae" (Marten et al. 2012: 289). Similarly to the present study, Marten et al. (2012) focused on towns which are close to international borders and/or which are tourist destinations. Differently from the present research, they accounted for both monolingual and multilingual signs; in addition, they analysed not only 
public signs, but also tourism websites. The only city that falls into the scope of this research and the study of Marten et al. (2012) is the Lithuanian resort town Druskininkai.

\section{Language policies in Lithuania and Poland: a short overview}

The present research was carried out in Poland and Lithuania, both of which are among the easternmost EU member states and both of which went through important societal and political transformations after the communist regime collapsed in 1989. Until then, both Poland and Lithuania were under the Soviet influence, but the degree of the communist rule and soviet domination in the two countries differed. Lithuania was occupied and belonged to the Soviet Union, whereas Poland existed as the Polish People's Republic and was a satellite state of the Soviet Union with more freedom than the republics of the Soviet Union.

The political situation had and still has a strong impact on the local language policies and the status of non-titular languages in the two countries. The Soviet regime was marked by the dominance of the Russian language in the whole communist bloc, but to a different extent in different countries. Though Poland was exposed to Russian through public media, it retained Polish as the titular language. Lithuania, in contrast, was dominated by Russian much more heavily. Russian was used as a lingua franca, and the situation in Lithuania was characterized by asymmetrical bilingualism with Russian dominating in high-level domains and in Russian-speaking minority groups (Marten et al. 2012: 290). Even now, in the former republics of the Soviet Union, Russian "continues to be a strong language" (Marten et al. 2012: 290), but this is not the case in the former satellite states of the Soviet Union, such as Poland, where Russian never had superior status. In spite of the former status of Russian, English is now the first foreign language in schools in both Poland and Lithuania and is used as the main lingua franca in international communication.

After 1989, the predominance of the Russian language ended in Lithuania after the country adopted the language law, which established Lithuanian as the state language. The Law on the State Language and the Lithuanian Constitution (see Appendix 1) establish unilingual policy, according to which public signs may only be in the state language. If other languages are used, they have to appear alongside Lithuanian and in smaller font than the inscription in Lithuanian. 
Similarly, in Poland, all the signage in public places must be provided in the state language (see Appendix 2). Public signs can include foreign language translations, but in accordance with the terms and conditions predetermined by the Ministry of Internal Affairs. Some languages, though, enjoy official bilingual street sign status in Poland; these include Belarusian, German, Kashubian, Lithuanian, and Ruthenian.

In both countries, the state language is heavily associated with national identity and has immense cultural importance. There is also a strong focus on language protection, which is reflected by the fact that both Poland and Lithuania have official language regulating institutions: the Polish Language Council and the Lithuanian Language Commission. Both institutions have the authority to set specific policies on language choices in the "top-down" model of language management (cf. Spolsky 2009: 31).

\section{Methodological framework}

The present study is grounded on a photographic database which was collected as part of the project "Language of Tourism: Linguistic Landscapes of Resorts" (funded by Kaunas Vytautas Magnus University, Lithuania). The following section describes the fieldwork area under study, the tools and procedures employed in data collection, and the principles of data analysis.

\subsection{Setting}

As has already been mentioned, the research area in the current study includes 3 Lithuanian resort towns and 2 Polish resort towns, all of which strongly focus on local and external tourism; in addition, they are all situated in the border area (on the coastline of the Baltic Sea and the border area between Poland and Lithuania); see Table 1 for more information. Sopot and Gdynia are part of the Tri-City, which also includes Gdansk; it is situated on the seaside and is one of Poland's main tourist attractions. The Lithuanian seaside cities Klaipedda and Palanga are also situated in close vicinity, and the distance between the two is only 30 kilometres. 
Table 1. Information about the cities under investigation

\begin{tabular}{l|c|c|c|c} 
& Population & Density (pop. per km²) & Area & Port \\
\hline PL & & & & \\
\hline Gdynia & 247799 & 1800 & $135 \mathrm{~km}^{2}$ & yes \\
\hline Sopot & 38141 & 2200 & $17,31 \mathrm{~km}^{2}$ & no \\
\hline LT & & & & \\
\hline Klaipeda & 157305 & 1605 & $98 \mathrm{~km}^{2}$ & yes \\
\hline Palanga & 17600 & 223 & $79 \mathrm{~km}^{2}$ & no \\
\hline Druskininkai & 14172 & 671 & $24 \mathrm{~km}^{2}$ & no
\end{tabular}

The Polish and Lithuanian cities are comparable in terms of the number of inhabitants, density of population, and the size of the area covered; in each country, one resort town has the status of a port.

For the interpretation of language distribution in multilingual signage, it is important to consider the main originating countries of tourists staying in the five resort towns. As Table 2 shows, there are more tourists from English-speaking countries in Poland, whereas in Lithuania tourists from Belarus and Russia outnumber all the other countries.

Table 2. Inbound tourism in Lithuania and Poland: top five countries (year 2014)

\begin{tabular}{l|c|l|c}
\multicolumn{2}{|c|}{ Lithuania } & \multicolumn{2}{c}{ Poland } \\
\hline Countries & Number of visitors & Countries & Number of visitors \\
\hline Belarus & 408000 & Germany & 1298702 \\
\hline Russia & 369200 & Russia & 409243 \\
\hline Latvia & 195500 & UK & 380917 \\
\hline Poland & 182900 & Ukraine & 275191 \\
\hline Germany & 166300 & USA & 215577
\end{tabular}

Adapted from: Lietuvos statistikos departamentas and The Central Statistical Office of Poland

These numbers will be important in the discussion of the results, and now we turn to the procedures of data collection and analysis. 


\subsection{Data collection and analysis}

The photographic evidence of LLs in Lithuania and Poland was obtained by taking pictures of all multilingual items and those monolingual signs that appeared in non-titular languages only. The signs were photographed in the central streets of the cities under investigation. To limit the scope of analysis, only stationary objects were selected in this investigation, and no movable items, such as newspapers, t-shirts, or vehicles, were photographed.

The photographic database used for the present research includes 329 signs in Poland (132 items in Sopot and 197 items in Gdynia) and 186 signs in Lithuania (52 items in Klaipeda, 70 items in Palanga, and 64 items in Druskininkai). In total, the data consists of 515 signs.

In quantitative studies of LL, the definition of what constitutes a sign is especially important. As is typical in quantitative LL studies, the present research applies the definition provided by Backhaus, who defines a sign as "any piece of written text within a spatially definable frame" (2006: 55). It is rather broad and includes anything from handwritten stickers to commercial billboards, and each sign is counted as one item, irrespective of its size.

Pictures were coded for a variety of variables, which include the following categories (based on Edelman 2010):

(1) survey area;

(2) government or private sign;

(3) type of establishment (e.g. a shop, a restaurant or a bank; also signs which do not belong to an establishment such as stickers);

(4) name of establishment;

(5) sector of shop;

(6) part of chain or independent;

(7) type of sign (e.g. name of establishment, security information, other shop sign, street sign, nameplate, sticker, poster, graffiti, etc.);

(8) number of languages and their ordering on the sign.

Thus, in the present survey, several broad categories were taken into account: the locale of multilingual signage, the number of languages and their distribution on signs, and the authorship of signs in non-titular languages. For the authorship of signs, we identified whether these were government or private signs. In case of private signs, the type of establishment and the type of the sign were considered. 
The issue of authorship is typically raised in LL studies by differentiating between government and private signs (e.g. Backhaus 2006, Ben Rafael et al. 2006). This dichotomy is based on the distinction between (a) "top-down" elements, the authors of which are institutional bodies acting under the control of local or central policies, and (b) "bottomup" elements, the authors of which are private individuals or groups of individuals who exercise no institutional power.

As suggested by Scollon and Scollon (2003) and Bruyèl-Olmedo and Juan-Garau (2009), the ordering of languages was assessed on the basis of physical layout within the text typical in western cultures (see):

(1) When texts were featured horizontally, L1 was the first language featured, reading from left to right;

(2) When texts were featured vertically, L1 was the first language found, reading from the top downwards;

(3) When a text was located centrally and/or appeared either in a larger or different font, it was regarded as L1 (Bruyèl-Olmedo and Juan-Garau 2009: 391).

As has already been mentioned, the data was analysed distributionally, noting the dominance of different languages in particular settings.

\section{Results}

The data obtained from the Polish and Lithuanian research sites is analysed in this section with regard to the authorship of multilingual signs, their distribution in different settings, and languages displayed in public signage.

\subsection{Authorship of multilingual signs}

Regarding the authorship of public signage, multilingual signs in the private sector make up around $90 \%$ of all signs and thus clearly outweigh government signs in both Lithuanian and Polish resort towns. As can be seen in Table 3, in two Lithuanian towns (Druskininkai and Palanga), multilingual government signs hardly appear. 
Table 3. Distribution of government and private signs

\begin{tabular}{l|c|c|c|c} 
& \multicolumn{2}{|c|}{ Government } & \multicolumn{2}{c}{ Private } \\
\hline \multicolumn{1}{c|}{ LT } & Occurrences & $\mathbf{\%}$ & Occurrences & $\mathbf{\%}$ \\
\hline Druskininkai & 3 & 4.8 & 60 & 95.2 \\
\hline Palanga & 1 & 1.4 & 69 & 98.6 \\
\hline Klaipeda & 14 & 28 & 36 & 72 \\
\hline Total: & $\mathbf{1 8}$ & $\mathbf{9 . 8}$ & $\mathbf{1 6 5}$ & $\mathbf{9 0 . 2}$ \\
\hline PL & & & & \\
\hline Gdynia & 6 & 3.1 & 189 & 96.9 \\
\hline Sopot & 34 & 26.4 & 95 & 73.6 \\
\hline Total: & $\mathbf{4 0}$ & $\mathbf{1 2 . 3}$ & $\mathbf{2 8 4}$ & $\mathbf{8 7 . 7}$
\end{tabular}

Multilingual government signs are more frequent in Polish than Lithuanian resort towns, but the difference is not substantial $(12.3 \%$ in Poland as opposed to $9.8 \%$ in Lithuania).

\subsection{Distribution of multilingual signage in different settings}

The distribution of signs in non-titular languages was analysed by coding the data for (a) categories generally common in touristic spots (i.e. shops, restaurants, hotels, banks, museums, galleries, tourist information offices, and information signs), (b) categories characteristic of coastal resort towns (i.e. boat companies), and (c) those generally typical of resorts (i.e. spas); see Table 4.

Table 4. Multilingual signage across different types of establishments

\begin{tabular}{|c|c|c|c|c|c|c|c|c|c|c|}
\hline & $\frac{\stackrel{े}{a}}{\omega}$ & 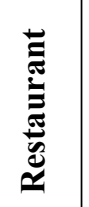 & 焉 & 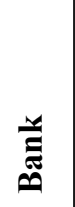 & $\frac{\tilde{a}}{n}$ & 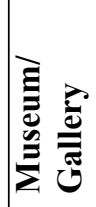 & 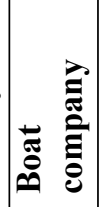 & 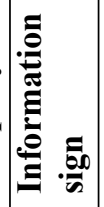 & $\underline{G}$ & 氖 \\
\hline \multicolumn{11}{|l|}{ LT } \\
\hline Druskininkai & 24 & 3 & 3 & 1 & 8 & 1 & 0 & 1 & 1 & 22 \\
\hline Klaipèda & 3 & 15 & 1 & 0 & 0 & 15 & 1 & 6 & 2 & 9 \\
\hline Palanga & 5 & 41 & 7 & 0 & 1 & 0 & 0 & 1 & 0 & 15 \\
\hline Total: & 32 & 59 & 11 & 1 & 9 & 16 & 1 & 8 & 3 & 46 \\
\hline$\%$ & 22.9 & 42.1 & 7.9 & 0.7 & 6.4 & 11.4 & 0.7 & 5.7 & 2.1 & 32.9 \\
\hline
\end{tabular}




\begin{tabular}{|c|c|c|c|c|c|c|c|c|c|c|}
\hline & $\frac{\hat{\theta}}{\tilde{n}}$ & 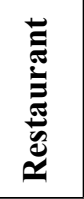 & 몽 & 节 & $\stackrel{\text { }}{\mathscr{S}}$ & 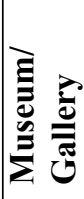 & 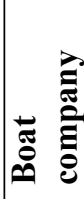 & 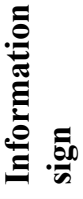 & $\underline{U}$ & \\
\hline \multicolumn{11}{|l|}{ PL } \\
\hline Gdynia & 53 & 41 & 1 & 11 & 0 & 5 & 0 & 30 & 0 & 55 \\
\hline Sopot & 25 & 40 & 1 & 1 & 1 & 16 & 4 & 11 & 7 & 26 \\
\hline Total: & 78 & 81 & 2 & 12 & 1 & 21 & 4 & 41 & 7 & 81 \\
\hline$\%$ & 31.6 & 32.8 & 0.8 & 4.9 & 0.4 & 8.5 & 1.7 & 16.6 & 2.8 & 32.8 \\
\hline
\end{tabular}

As perhaps could be expected, the majority of signs in non-titular languages belong to restaurants $(42.1 \%$ in Lithuania and $32.8 \%$ in Poland). In Poland, shops employ multilingual signs almost as frequently as restaurants (31.6\% as contrasted to $22.9 \%$ in Lithuania).

With regard to the status of shops as being independent or part of international, national, and regional chains, some interesting crosscountry differences emerged. As Table 5 shows, in Lithuania, the vast majority of multilingual signs belong to independent shops (133 occurrences, or $81.6 \%$ ) in contrast to just a single occurrence of a multilingual sign on a shop that is part of an international chain. In Poland, multilingual signs in the category of independent shops also prevail (82 occurrences, or $29.6 \%$ ), but multilingual signs on shops that are part of international chains are of a similar frequency (70 occurrences, or $25.3 \%$ ). Non-titular languages are also highly frequent in the signage of Polish shops that are part of national chains (48 occurrences, or 17.3\%).

Table 5. Part of chain or independent?

\begin{tabular}{|c|c|c|c|c|c|}
\hline & $\begin{array}{c}\text { Interna- } \\
\text { tional chain }\end{array}$ & $\begin{array}{c}\text { National } \\
\text { chain }\end{array}$ & $\begin{array}{c}\text { Regional } \\
\text { chain }\end{array}$ & $\begin{array}{c}\text { Inde- } \\
\text { pendent }\end{array}$ & Unknown \\
\hline \multicolumn{6}{|l|}{ LT } \\
\hline Druskininkai & 0 & 4 & 2 & 40 & 8 \\
\hline Klaipėda & 0 & 6 & 0 & 30 & 4 \\
\hline Palanga & 1 & 1 & 0 & 63 & 4 \\
\hline Total: & $1(0.6 \%)$ & $11(6.8 \%)$ & $2(1.2 \%)$ & $133(81.6 \%)$ & $16(9.8 \%)$ \\
\hline \multicolumn{6}{|l|}{ PL } \\
\hline Gdynia & 47 & 40 & 4 & 57 & 35 \\
\hline Sopot & 23 & 8 & 6 & 25 & 32 \\
\hline Total: & $70(25.3 \%)$ & $48(17.3 \%)$ & $10(3.6 \%)$ & $82(29.6 \%)$ & $67(24.2 \%)$ \\
\hline
\end{tabular}


These results might have been predetermined by economic factors, such as the absence of (inter)national or regional chain shops in the central area of Lithuanian resort towns, but to confirm it, additional research would be necessary.

The results related to the shop sector also demonstrate some interesting differences between the LL in Polish and Lithuanian resort towns, one of which is the high incidence of multilingual signage on souvenir shops in Lithuania (see Table 6). There is just a single occurrence of a multilingual sign on a souvenir shop in Poland, but in Lithuania souvenir shops are the main type of shops that employ non-titular languages. Since souvenir shops are typically associated with the tourism sector, the findings in Poland were not as anticipated, whereas Lithuanian results were in line with initial expectations.

Table 6. Sector of shop

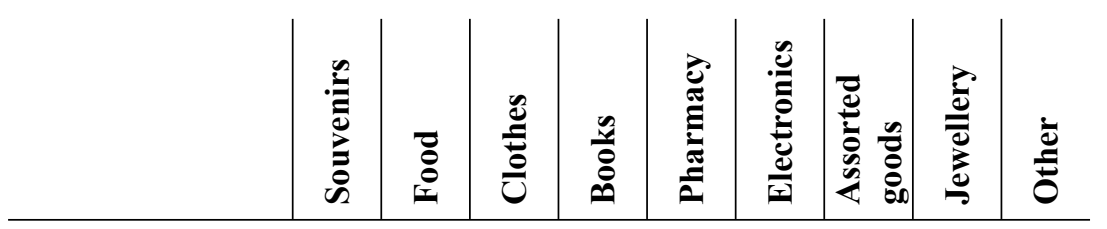

LT

\begin{tabular}{l|r|r|r|r|r|r|r|r|r}
\hline Druskininkai & 7 & 1 & 7 & 1 & 0 & 0 & 0 & 5 & 5 \\
\hline Klaipèda & 5 & 0 & 1 & 0 & 0 & 0 & 0 & 0 & 0 \\
\hline Palanga & 2 & 2 & 1 & 0 & 0 & 0 & 0 & 0 & 2 \\
\hline Total: & $\mathbf{1 4}$ & $\mathbf{3}$ & $\mathbf{9}$ & $\mathbf{1}$ & $\mathbf{0}$ & $\mathbf{0}$ & $\mathbf{0}$ & $\mathbf{5}$ & $\mathbf{7}$ \\
\hline \% & $\mathbf{3 5 . 9}$ & $\mathbf{7 . 7}$ & $\mathbf{2 3 . 1}$ & $\mathbf{2 . 6}$ & $\mathbf{0}$ & $\mathbf{0}$ & $\mathbf{0}$ & $\mathbf{1 2 . 8}$ & $\mathbf{1 7 . 9}$ \\
\hline
\end{tabular}

PL

\begin{tabular}{l|r|r|r|r|r|r|r|r|r}
\hline Gdynia & 0 & 12 & 10 & 3 & 3 & 4 & & 5 & 16 \\
\hline Sopot & 1 & 4 & 7 & 0 & 2 & 0 & 1 & 0 & 14 \\
\hline Total: & $\mathbf{1}$ & $\mathbf{1 6}$ & $\mathbf{1 7}$ & $\mathbf{3}$ & $\mathbf{5}$ & $\mathbf{4}$ & $\mathbf{1}$ & $\mathbf{5}$ & $\mathbf{3 0}$ \\
\hline \% & $\mathbf{1 . 2}$ & $\mathbf{1 9 . 5}$ & $\mathbf{2 0 . 7}$ & $\mathbf{3 . 7}$ & $\mathbf{6 . 1}$ & $\mathbf{4 . 9}$ & $\mathbf{1 . 2}$ & $\mathbf{6 . 1}$ & $\mathbf{2 3 . 6}$
\end{tabular}

In Poland, interestingly, the shop sectors where the largest proportions of multilingual LL appeared are clothes and food shops (16 and 17 occurrences respectively). These shops might be relevant for tourists, but they are just as important for local citizens, so non-titular languages can be assumed to serve a primarily symbolic function on them instead of or in addition to the informational function. 
The photographic evidence has revealed that in both Poland and Lithuania, the most dominant type of multilingual signs is the name of the establishment (24.5\% and $24.5 \%$ respectively). Another large category of multilingual signs is that of posters (14\% in Lithuania and $18 \%$ in Poland).

Table 7. Types of multilingual signs

\begin{tabular}{|c|c|c|c|c|c|c|c|c|}
\hline 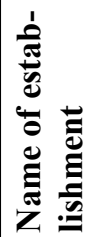 & 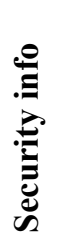 & 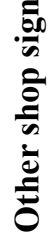 & 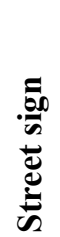 & 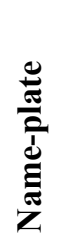 & 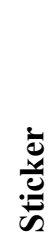 & $\begin{array}{l}\bar{D} \\
0 \\
0\end{array}$ & $\stackrel{\Xi}{2}$ & \\
\hline
\end{tabular}

LT

\begin{tabular}{l|r|r|r|r|r|r|r|r|r|r}
\hline Druskininkai & 16 & 0 & 7 & 0 & 0 & 1 & 10 & 2 & 0 & 28 \\
\hline Klaipèda & 12 & 0 & 12 & 1 & 4 & & 11 & 1 & 0 & 11 \\
\hline Palanga & 17 & 2 & 7 & 0 & 9 & 2 & 5 & 6 & 2 & 20 \\
\hline Total: & $\mathbf{4 5}$ & $\mathbf{2}$ & $\mathbf{2 6}$ & $\mathbf{1}$ & $\mathbf{1 3}$ & $\mathbf{3}$ & $\mathbf{2 6}$ & $\mathbf{9}$ & $\mathbf{2}$ & $\mathbf{5 9}$ \\
\hline \% & $\mathbf{2 4 . 2}$ & $\mathbf{1 . 1}$ & $\mathbf{1 4}$ & $\mathbf{0 . 5}$ & $\mathbf{7}$ & $\mathbf{1 . 6}$ & $\mathbf{1 4}$ & $\mathbf{4 . 8}$ & $\mathbf{1 . 1}$ & $\mathbf{3 1 . 7}$ \\
\hline PL
\end{tabular}

PL

\begin{tabular}{l|r|r|r|r|r|r|r|r|r|r}
\hline Gdynia & 54 & 4 & 23 & 3 & 5 & 9 & 29 & 47 & 10 & 13 \\
\hline Sopot & 26 & 6 & 10 & 1 & 3 & 8 & 30 & 15 & 7 & 24 \\
\hline Total: & $\mathbf{8 0}$ & $\mathbf{1 0}$ & $\mathbf{3 3}$ & $\mathbf{4}$ & $\mathbf{8}$ & $\mathbf{1 7}$ & $\mathbf{5 9}$ & $\mathbf{6 2}$ & $\mathbf{1 7}$ & $\mathbf{3 7}$ \\
\hline \% & $\mathbf{2 4 . 5}$ & $\mathbf{3 . 1}$ & $\mathbf{1 0 . 1}$ & $\mathbf{1 . 2}$ & $\mathbf{2 . 4}$ & $\mathbf{5 . 2}$ & $\mathbf{1 8}$ & $\mathbf{1 9}$ & $\mathbf{5 . 2}$ & $\mathbf{1 1 . 3}$
\end{tabular}

A striking difference between Polish and Lithuanian LLs is the difference in the frequency of non-titular languages on special offers $(9$ occurrences, or $4.8 \%$ in Lithuania as contrasted to 62 occurrences, or $19 \%$ in Poland). Surprisingly, multilingual outside menus are considerably less frequent in Lithuanian resort towns (only 2 occurrences in contrast to 17 instances in Poland).

\subsection{Languages featured in the $L L$}

As has already been noted, the signs under investigation were coded and analysed for the number of languages featured on multilingual signs and their sequencing; the study also took into account which languages 
featured on LL and in what combinations. The results show that bilingual signs dominate substantially in both Poland and Lithuania, but their dominance in Poland is particularly striking when compared to Lithuania. In Polish resort towns, almost all signs (92.4\%) are bilingual, whereas in Lithuania such signs make up nearly $60 \%$.

Table 8. Number of languages on multilingual signs

\begin{tabular}{l|r|r|r|r|r} 
& \multicolumn{6}{|c}{ Number of languages } \\
\hline LT & $\mathbf{2}$ & $\mathbf{3}$ & $\mathbf{4}$ & $\mathbf{5}$ & $\mathbf{2 3}$ \\
\hline Druskininkai & 38 & 18 & 8 & 0 & 0 \\
\hline Klaipėda & 40 & 9 & 3 & 0 & 0 \\
\hline Palanga & 33 & 31 & 5 & 0 & 1 \\
\hline TOTAL: & $\mathbf{1 1 1}(\mathbf{5 9 . 7 \% )}$ & $\mathbf{5 8 ( 3 1 . 2 \% )}$ & $\mathbf{1 6}(\mathbf{8 . 6 \%})$ & $\mathbf{0}$ & $\mathbf{1 ( 0 . 5 \% )}$ \\
\hline PL & & & & & \\
\hline Gdynia & 188 & 8 & 0 & 1 & 0 \\
\hline Sopot & 116 & 14 & 1 & 1 & 0 \\
\hline TOTAL: & $\mathbf{3 0 4}(\mathbf{9 2 . 4 \% )}$ & $\mathbf{2 2 ( 6 . 7 \% )}$ & $\mathbf{1 ~ ( 0 . 3 \% )}$ & $\mathbf{2 ( 0 . 6 \% )}$ & $\mathbf{0}$
\end{tabular}

It was an unexpected finding that Lithuanian LLs displayed a larger proportion of multilingual signs which include more than two languages. In Lithuanian resorts, trilingual signs appear in approximately one third of cases, and in Poland they make up only $6.7 \%$. In Lithuania, signs in four languages make up $8.6 \%$ in contrast to a single instance in Poland. An extreme and interesting case in Lithuanian LL is the sign which displays as many as 23 languages.

In terms of the languages featured in the LL of resorts, the present study has revealed that English clearly dominates in Poland (300 signs, or $88.8 \%$ ) and is the most common in Lithuania as well (147 signs, or $52.7 \%)$. German is used to a similar extent in both countries $(8.8 \%$ of signs in Poland and $6.1 \%$ in Lithuania), but it is considerably less frequent than English: it is 10 times less frequent in Poland and almost 9 times less frequent than English in Lithuania. Though Germany is Poland's neighbouring country and its citizens are the most numerous group of tourists in Poland, the number of occurrences of German is surprisingly low. In Lithuania, German tourists are the fourth largest group of tourists, so the lower frequency of German in public signs is more readily explicable, but it is still relatively very low. 
Table 9. Languages featured in the Polish and Lithuanian LL

\begin{tabular}{l|r|r|r|r|r|r} 
& English & Russian & German & Italian & French & \multicolumn{2}{|c}{ Polish } \\
\hline LT & & & & & & 11 \\
\hline Druskininkai & 44 & 40 & 3 & 0 & 0 & 0 \\
\hline Klaipėda & 47 & 10 & 9 & 2 & 2 & 0 \\
\hline Palanga & 56 & 50 & 5 & 0 & 0 & $\mathbf{1 1}$ \\
\hline Total: & $\mathbf{1 4 7}$ & $\mathbf{1 0 0}$ & $\mathbf{1 7}$ & $\mathbf{2}$ & $\mathbf{2}$ & $\mathbf{3 . 9}$ \\
\hline \% & $\mathbf{5 2 . 7}$ & $\mathbf{3 5 . 8}$ & $\mathbf{6 . 1}$ & $\mathbf{0 . 7}$ & $\mathbf{0 . 7}$ & 0 \\
\hline PL & & & & & & Lithuanian \\
\hline Sopot & 129 & 2 & 10 & 5 & 3 & 0 \\
\hline Gdynia & 171 & 0 & 21 & 6 & 7 & $\mathbf{0}$ \\
\hline Total: & $\mathbf{3 0 0}$ & $\mathbf{2}$ & $\mathbf{3 1}$ & $\mathbf{1 1}$ & $\mathbf{1 0}$ & $\mathbf{0}$
\end{tabular}

Despite the existing similarities with regard to the use of English and German, the two countries differ dramatically in the use of Russian. It is hardly ever used in Poland ( 2 signs, or $0.6 \%$ ), whereas in Lithuania it is the second most frequent language (100 signs, or $35.8 \%)$. This striking difference can be partly related to the dominance of Belarusian and Russian tourists in Lithuania, who are the most numerous tourists there. However, the absence of Russian in the Polish LL is perhaps more associated with the symbolic value or prestige of Russian rather than the tourists' background. Russia and Belarus are among the top five countries in terms of the number of tourists in Poland, so it could be expected to be present in public signage in touristic spots.

Languages that are encountered in Poland especially rarely (once or twice) are not represented in Table 9; such languages include Spanish ( 2 occurrences), Slovenian ( 2 occurrences), Japanese ( 2 occurrences), Georgian, Greek, and Turkish. In Lithuania, there is a single occurrence of Latin.

Interestingly, Lithuanian does not appear in the LL of Sopot or Gdynia; Polish, meanwhile, appears in Lithuania, but only in Druskininkai, which is situated just around 50 kilometres away from the Polish border, and thus receives a large number of Polish tourists (cf. the results of Marten et al. 2012).

Though the majority of multilingual signs include the titular language as the first and most dominant language, on a number of signs English is used as the first or only language (18 signs, or 9.7\% in Lithuania and 125 signs, or $38 \%$ in Poland). This result perhaps can be interpreted as 
an indication of stronger bottom-down policies in Lithuania. As was mentioned in the overview of language policies in both countries, all public signs should appear in the state language in both Poland and Lithuania; if the sign is in more than one language, the titular language should appear first and in a larger font. Signs with English as the first language are a violation of this regulation; interestingly, such signs are four times more frequent in Poland than Lithuania. Such signs, which are actually authored by non-government establishments, can be treated as "bottom-up" elements, which question national policies and prioritise the economic and symbolic value of the foreign language.

The distribution of different language combinations across different resort towns has revealed that there are some differences not only between countries, but also between towns and cities within the same country. In Lithuania, multilingual signs including Russian do not appear in Klaipeda, where a large Russian minority lives. However, they often occur in Druskininkai and especially frequently in Palanga, both of which are very popular resorts among Russian and Belarusian tourists. In addition, English as the first language occurs mainly in Klaipeda, but not in the other resorts, which makes it similar to Sopot in Poland (see Table 10).

Table 10. Language combinations on multilingual signs

\begin{tabular}{l|c|l|r} 
Druskininkai & $\begin{array}{c}\text { Occur- } \\
\text { rences }\end{array}$ & \multicolumn{1}{c}{ Gdynia } & $\begin{array}{c}\text { Occur- } \\
\text { rences }\end{array}$ \\
\hline Lithuanian-English & 18 & Polish-English & 158 \\
\hline Lithuanian-Russian & 11 & Polish-German & 15 \\
\hline Lithuanian-English-Russian & 7 & Polish-English-German & 5 \\
\hline Klaipėda & & Sopot & \\
\hline Lithuanian-English & 28 & Polish-English & 76 \\
\hline English-Lithuanian & 6 & English-Polish & 28 \\
\hline Lithuanian-English-German & 4 & Polish-English-German & 9 \\
\hline Palanga & & & \\
\hline Lithuanian-English-Russian & 23 & & \\
\hline Lithuanian-English & 18 & &
\end{tabular}

Interestingly, in Lithuania, German appears on trilingual signs only in Klaipeda, which historically used to belong to Germany. In Poland, conversely, a stronger preference for German is observed in Gdynia than Sopot, though tourism in both resorts is strongly dominated by Germans. 


\section{Conclusion}

The present research was grounded on the stance that languages displayed in the LL of a location are not necessarily a reflection of ethnolinguistic vitality of minority languages (especially in linguistically more homogeneous countries like Lithuania and Poland). LL can also reveal some tendencies preconditioned by language attitudes and, importantly, economic factors, such as tourism. As the findings reported in this paper demonstrate, linguistic heterogeneity in Lithuanian and Polish LLs does relate (at least partly) to tourist exchange in the neighbouring countries.

The evidence of multilingual LLs in both Lithuania and Poland suggests that English dominates here as a lingua franca and as a main language of tourism. German is the second most frequent language in Poland and the third most frequent language in Lithuania, but it is considerably less common than English. On the one hand, Poland's neighbourhood with Germany and the flows of German tourists in Poland and Lithuania may not seem to have a considerable impact on its use in LL. On the other hand, German is more frequent than French, Italian, or Spanish in both countries, which means that LL does reflect the tourist flows at least to some extent.

With regard to the dominance of English, the current results observed in Lithuania can be compared to Muth's (2008) findings obtained in his study of LL in Vilnius, which clearly evidenced the dominance of English over Russian and all the other foreign languages used in public signage. Muth's investigation demonstrated that in Vilnius Old Town, monolingual English signs appear in 16\% and Lithuanian-English signs constitute $30 \%$ of all the cases. In contrast, Russian and LithuanianRussian signs do not exceed 1\% (cf. Petzold and Berns 2000). Though Vilnius is a multi-ethnic city with relatively large Russian and Polish minorities, Russian and Polish hardly ever appear in the public signage in Vilnius Old Town.

However, the limited use of Russian in Vilnius observed by Muth (2008) contrasts greatly with its distribution in the Lithuanian resort towns in the current study. Russian is the second most frequent language in Lithuanian LLs and constitutes more than one third of all multilingual signs. On Polish signs, meanwhile, there are no instances of Russian, though one might expect a different trend on the basis of tourist flows. Thus, the results in Lithuanian resorts cannot be explained solely by the large tourist flows from Russia and Belarus. Such results may suggest that Russian is viewed differently in the former republics of the Soviet 
Union. There might also be a difference between urban and rural areas: Vilnius in Muth (2008) and Klaipeda in this study are presumably more international and thus use English as the main lingua franca, whereas smaller towns like Palanga and Druskininkai are more sensitive to the larger groups of incoming tourists and cater to their needs.

Regarding the titular languages of the neighbouring countries, it was initially expected in this study that these languages would be present in public signage. The findings have revealed, though, that neighbouring with a country does not necessarily lead to the presence of its language in LL. This is evidenced by the absence of Latvian in Lithuanian resorts and the absence of Russian and Lithuanian in Polish resorts. Interestingly, in Lithuania, Polish appears only in Druskininkai, which is very close to the border between Lithuania and Poland.

In both Lithuania and Poland, multilingual signs dominate on restaurants and shops. However, signs in non-titular languages appear on chain shops much more commonly in Poland than Lithuania. In Lithuania, such signs dominate on independent shops, many of which are souvenir shops. This might indicate that Lithuanian chain shops are more inclined to observe the language law, or this might be conditioned by the absence of chain shops in touristic areas.

The present analysis of the authorship of multilingual signs shows that multilingual signs dominate in the private sector, which means that bottom-up elements dominate in both Polish and Lithuanian resort towns. The lower incidence of multilingual government signs is in line with some previous research, so it is not an unexpected finding. What was unforeseen is that monolingual English signs on private establishments in Poland considerably outweigh such signs in Lithuania. These findings might indicate that language policies in Lithuania have more authority and power than those in Poland. Though language laws formally allow for a similar degree of flexibility and set out very similar requirements for the use of the state language in both countries, bottomup agency is more prevalent in Poland.

\section{Acknowledgements}

I would like to express my gratitude to Frederik Heinrich Bissinger and Zarina Rakhmanova, the students of the International Master's in Sociolinguistics and Multilingualism, who participated in the project "Language of Tourism: Linguistic Landscapes of Resorts". 


\section{Appendix 1: Law on the State Language in Lithuania}

\section{Law on the State Language in Lithuania}

(quoted from: http://www3.lrs.lt/docs2/NCYNKNNN.PDF)

Article 16. Names of all enterprises, offices and organizations, functioning in the Republic of Lithuania shall be formed adhering to the norms of the Lithuanian language and the rules approved by the State Lithuanian Language Commission under the Seimas of the Republic of Lithuania.

\section{SIGNS AND INFORMATION}

Article 17. In the Republic of Lithuania public signs shall be in the state language. Seals, stamps, letterheads, plaques, signs in offices and other places of enterprises, institutions and organizations of the Republic of Lithuania, as well as names of goods and services provided in Lithuania and their descriptions, must be in the state language.

Article 18. Names of organizations of ethnic communities, their informational signs may be rendered in other languages along with the state language. The format of signs in other languages cannot be larger than that of signs in the state language.

\section{CORRECTNESS OF THE STATE LANGUAGE}

Article 19. The State shall enhance the prestige of the correct Lithuanian language, provide conditions for protecting linguistic norms, personal names, place-names, dialects and written language monuments, ensure the material basis for the state language functioning, provide general assistance to the Lithuanian language studies as a priority scientific branch and to the scholarly institutions which study this language, as well as to publishing of books on the Lithuanian language science and practice.

Article 20. The State Lithuanian Language Commission shall establish the trends and tasks of the state language protection and approve linguistic norms.

$[\ldots]$

Article 22. Mass media of Lithuania (the press, television, radio, etc.), all publishers of books and other publications must observe the norms of the correct Lithuanian language.

Article 23. All public signs must be correct. 


\section{Appendix 2: Law on the State Language in Poland}

\section{The Act on the Polish Language}

(quoted from: http://rjp.pan.pl/images/stories/pliki/broszury/jp_angielski.pdf)

The Polish Language Act stipulates the aims, scope and means of the language policy in respect of the Polish language which is both the native language of most of the country's citizens and the official language of the state which, in turn, is a common good of all Polish citizens.

The Act was passed by Parliament in accordance with the preamble:

- because Polish is perceived as being a basic element of national identity and one of the nation's cultural achievements;

- taking into consideration historical experience when the invading and dominating powers fought against the Polish language in order to deprive the people of their national identity;

- recognizing the need to protect the national identity against the process of globalization;

- recognizing that Polish culture contributes to creating a common, culturally-varied Europe, and its preservation and development is possible only through the protection of the Polish Language.

These reasons justify the following responsibilities (also mentioned in the Act):

- caring for the public use of the language and improving the abilities of its speakers as well as creating conditions for proper development of the language as a tool for communicating in all aspects of life;

- promoting knowledge of the language, and its importance in Polish culture;

- propagating respect for regional dialects and languages, as well as preventing their disappearance;

- promoting the language around the world;

- providing assistance in learning the language in Poland and outside its boundaries. 


\author{
Address: \\ Jūratè Ruzaitè \\ Vytautas Magnus University \\ Faculty of Humanities \\ K. Donelaičio g. 52-217 \\ LT-44240 Kaunas, Lietuva \\ E-mail: jurate.ruzaite@vdu.lt
}

\title{
References
}

Backhaus, Peter (2006) "Multilingualism in Tokyo: a look into the linguistic landscape". International Journal of Multilingualism 3, 1, 52-66.

Backhaus, Peter (2009) "Rules and regulations in linguistic landscaping: a comparative perspective. In Elana Shohamy and Durk Gorter, eds. Linguistic landscapes: expanding the scenery, 157-172. New York: Routledge.

Ben-Rafael, Eliezer, Elana Shohamy, Muhammad Hasan Amara, and Nira TrumperHecht (2006) "Linguistic landscape as symbolic construction of the public space: the case of Israel". International Journal of Multilingualism 31, 7-30.

Bruyèl-Olmedo, Antonio and Maria Juan-Garau (2009) "English as a lingua franca in the linguistic landscape of the multilingual resort of S'Arenal in Mallorca". International Journal of Multilingualism 6, 4, 386-411.

Cenoz, Jasone and Durk Gorter (2006) "Linguistic landscape and minority languages". International Journal of Multilingualism 3, 1, 67-80.

Coluzzi, Paolo (2009) "The Italian linguistic landscape: the cases of Milan and Udine". International Journal of Multilingualism 6, 3, 298-312.

Curtin, Melissa L. (2015) "Creativity in polyscriptal typographies in the linguistic landscape of Taipei”. Social Semiotics 25, 2, 236-243.

Dagenais, Diane, Danièle Moore, Cécile Sabatier, Patricia Lamarre, and Françoise Armand (2009) "Linguistic landscape and language awareness". In Elana Shohamy and Durk Gorter, eds. Linguistic landscapes: expanding the scenery, 253-269. London: Routledge.

Edelman, Loulou (2010) Linguistic landscapes in the Netherlands: a study of multilingualism in Amsterdam and Friesland. Utrecht: LOT.

Gendelman, Irina and Giorgia Aiello (2010) "Faces of places: façades as global communication in post-Eastern bloc urban renewal". In Adam Jaworski and Crispin Thurlow, eds. Semiotic landscapes: language, image, space, 256-273. London: Continuum.

Gorter, Durk (2006) "Further possibilities for linguistic landscape research". International Journal of Multilingualism 3, 1, 81-90.

Haarmann, Harald (1989) Symbolic values of foreign language use. New York, NY: Mouton de Gruyter. 
Huebner, Thom (2006) "Bangkok's linguistic landscapes: environmental print, codemixing and language change". International Journal of Multilingualism 3, 1, 30-57.

Jaworski, Adam (2010) "Linguistic landscapes on postcards: tourist mediation and the sociolinguistic communities of contact”. Sociolinguistic Studies 4, 3, 569-594.

Kallen, Jeffery (2009) "Tourism and representation in the Irish linguistic landscape". In Ella Shohamy and Durk Gorter, eds. Linguistic landscapes: expanding the scenery, 270-283. New York: Routledge.

Koschade, Adam (2016) "Willkommen in Hahndorf: a linguistic landscape of Hahndorf, South Australia”. International Journal of Humanities and Cultural Studies 3, 1, 692-716.

Landry, Rodrigue and Richard Y. Bourhis (1997) "Linguistic landscape and ethnolinguistic vitality: an empirical study”. Journal of Language and Social Psychology 16, 1, 23-49.

Malinowski, David (2009) "Authorship in the linguistic landscape: a multimodalperformative view". In Shohamy and Druk Gorter, eds. Linguistic landscapes: expanding the scenery, 107-125. New York: Routledge.

Manan, Syed Abdul, Maya Khemlani David, Francisco Perlas Dumanig, and Khan Naqeebullah (2015) "Politics, economics and identity: mapping the linguistic landscape of Kuala Lumpur, Malaysia”. International Journal of Multilingualism 12, $1,31-50$.

Marten, Heiko F. (2012) “'Latgalian is not a language’: linguistic landscapes in Eastern Latvia and how they reflect centralist attitudes". In Durk Gorter, Luk Van Mensel, and Heiko F. Marten, eds. Minority languages in the linguistic landscape, 19-35. Houndmills: Palgrave Macmillan.

Marten, Heiko F., Sanita Lazdiņa, Solvita Pošeiko, and Sandra Murinska (2012) "Between old and new killer languages? Linguistic transformation, lingua francas and languages of tourism in the Baltic States". In Christine Hélot, Monica Barni, Rudi Janssens, and Carla Bagna, eds. Linguistic landscapes, multilingualism and social change: diversité des approaches, 289-308. Frankfurt: Peter Lang.

Masai, Yasuo (1972) Living map of Tokyo. Tokyo: Jiji Tsushinsha.

Ministry of Justice of Lithuania (1995) Law on the state language. Available online at $<$ http://www.litlex.lt/Litlex/Eng/Frames/Laws/Fr_laws.htm.>.

Accessed on 24.02.2017.

Moriarty, Máiréad (2014) "Contesting language ideologies in the linguistic landscape of an Irish tourist town“. International Journal of Bilingualism 18, 5, 464-477.

Muth, Sebastian (2008) "Multiethnic but multilingual as well? -The linguistic landscapes of Vilnius". In Said Sahel and Ralf Vogel (Hg.), eds. Norddeutsches linguistisches kolloquium, 121-146. Available online at <http://biecoll.ub.uni-bielefeld. de/volltexte/2009/2007/pdf/Muth_NLK08.pdf $>$. Accessed on 24.02.2017.

Muth, Sebastian (2012) "The linguistic landscapes of Chişinău and Vilnius: linguistic landscape and the representation of minority languages in two post-soviet capitals". In Durk Gorter, Luk Van Mensel, and Heiko F. Marten, eds. Minority languages in the linguistic landscape, 204-224. Houndmills: Palgrave Macmillan. 
Niño-Murcia, Mercedes (2003) “"English is like the dollar': hard currency ideology and the status of English in Peru". World Englishes 22, 2, 121-142.

Ovesdotter, Cecilia (2003) "English in the Ecuadorian commercial context". World Englishes 22, 2, 143-158.

Pavlenko, Aneta (2009) "Language conflict in post-soviet linguistic landscapes". Journal of Slavic Linguistics 17, 1-2, 247-274.

Pavlenko, Aneta (2010) "Linguistic landscape of Kyiv, Ukraine: a diachronic study". In Elana Shohamy, Eliezer Ben-Rafael, and Monica Barni, eds. Linguistic landscape in the city, 133-150. Bristol: Multilingual Matters.

Peck, Amiena and Felix Banda (2014) “Observatory's linguistic landscape: semiotic appropriation and the reinvention of space". Social Semiotics 24, 3, 302-323.

Petzold, Ruth and Margie Berns (2000) "Catching up with Europe: speakers and functions of English in Hungary". World Englishes 19, 1, 113-124.

Pošeiko, Solvita (2015) "The Latvian language in the linguistic landscape of Daugavpils (the middle of the 19th century-today". Journal of Education Culture and Society 2, 320-336.

Reh, Mechthild (2004) "Multilingual writing: a reader-oriented typology with examples from Lira municipality (Uganda)". International Journal of the Sociology of Language 170, 1-41.

Rosenbaum, Yehudit, Elizabeth Nadel, Robert L. Cooper, and Joshua Fishman (1977) "English on Keren Kayemet Street". In Joshua A. Fishman, Robert L. Cooper, and Andrew W. Conrad, eds. The spread of English. Rowley, MA: Newbury House, 179-196.

Ruzaitè, Jūratė (2006) "Lithuanian shop signs: national or international?" In Ineta Savickienè, ed. Language, diversity and integration in the enlarged EU: Challenges and opportunities, 213-226, Kaunas: Vytautas Magnus University.

Scollon, Ron and Suzie Scollon (2003) Discourses in place: language in the material world. London: Routledge.

Sebba, Mark (2012) "Multilingualism in written discourse: an approach to the analysis of multilingual texts". International Journal of Bilingualism 17, 1, 97-118.

Shibliyev, Javanshir (2014) "Linguistic landscape approach to language visibility in post-soviet Baku". Bilig 71, 205-232.

Available at $<$ http://bilig.yesevi.edu.tr/yonetim/icerik/makaleler/28-published.pdf $>$. Accessed on 03.11.2016.

Shohamy, Elana and Shoshi Waksman (2009) "Linguistic landscape as an ecological arena". In Elana Shohamy and Durk Gorter, eds. Linguistic landscapes: expanding the scenery, 313-331. London: Routledge.

Spolsky, Bernard (2004) Language policy. Cambridge: Cambridge University Press.

Spolsky, Bernard (2007) "Towards a theory of language policy". Working papers in educational linguistics 22, 1, 1-14.

Spolsky, Bernard (2009) "Prolegomena to a sociolinguistic theory of public signage". In Ellana Shohamy and Durk Gorter, eds. Linguistic landscapes: expanding the scenery, 25-39. New York: Routledge. 
Torkington, Kate (2014) "Tourism-related mobilities and discursive landscaping in the Algarve". Dos Algarves: a multidisciplinary e-journal, 24, 40-62. Available online at $<\mathrm{http}$ ://www.dosalgarves.com/rev/N24/4rev24.pdf $>$. Accessed on 07.11.2016.

Yan, Libo and Maria Younghee Lee (2014) "Tourist perceptions of the multi-linguistic landscape in Macau". Journal of China Tourism Research 10, 4, 432-447.

Yurchak, Alexei (2000) "Privatize your name: symbolic work in a post-soviet linguistic market". Journal of Sociolinguistics 4, 3, 406-434.

Xiu, Na and Lisheng Li (2016) "Studying languages in the linguistic landscape of Lijiang Old Town". International Journal of English Linguistics 6, 2, 105-117.

Kokkuvõte. Jūratẻ Ruzaitė: Turismi keelemaastik: mitmekeelsed sildid Leedu ja Poola kuurortides. Artikkel käsitleb Poola ja Leedu piirialal paiknevate kuurortlinnade keelemaastikku. Artikli keeleainestikuks on 515 linnakeskustest ja seega turistidele enim huvi pakkuvatest linnaosadest kogutud mitmekeelset silti. Uurimuse põhieesmärk on selgitada välja, kes on avalike siltide autorid ja mis asutused (ettevõtted, institutsioonid) neid kasutavad, ning analüüsida, millised keeled populaarsetes turismisihtkohtades kõrvuti eksisteerivad. Tulemuste tõlgendamisel toetub autor mitmekeelsete avalike siltide, turismi kui olulise majandusteguri ning ametlike keelepoliitikate vahelistele seostele. Tulemused näitavad, et vähemalt mõned suundumused avalike siltide keelevalikutes on seotud turismi ja turistide vajadustega. Seevastu mõnede teiste trendide analüüsimisel (nt vene keele puudumine Poola keelemaastikul) tuleb arvesse võtta muid mitteametlike keeltega seonduvaid sümboolseid, majanduslikke ja ideoloogilisi väärtusi.

Märksõnad: keelemaastik, mitmekeelsed sildid, leedu keel, poola keel, turism, kuurordid, piiriala 